Ann. Biol. anim. Bioch. Biophys., 1978, 18 (2 B), 351-357.

\title{
Germinal and somatic cell interrelationships in gonadal sex differentiation
}

\author{
by Wai-Sum $O\left({ }^{1}\right)$, T. G. BAKER * \\ MRC Unit of Reproductive Biology, 2 Forrest Road, Edinburgh, Scotland \\ * Department of Obstretrics and Gynaecology, University of Edinburgh, Edinburgh Scolland, U. K.
}

Summary. The influence of somatic cells affecting the differentiation and development of germ cells in gonadal differentiation is discussed. It has been confirmed that both the male and the female germ cells can be induced to enter meiosis under the influence of the rete ovarii. The interaction between germinal and somatic cells is also investigated using an « artificial » chimaeric gonad which contains somatic and germinal cells of opposite sexes. The results indicate that $X Y$ germ cells can survive in the $X X$ somatic environment and are induced to enter meiosis precociously while $X X$ germ cells fail to survive in an $X Y$ somatic environment.

One of the major differences between the sexual differentiation of the ovary and testis is the time at which meiosis in the germ cells commences: in the female meiosis occurs during fetal life while in males it does not start until around the time of puberty (see Baker and 0, 1976 ; Zuckerman and Baker, 1977). In mammals, it is difficult to assess whether meiosis is actively induced in the ovary, prevented in the pre-pubertal testis, or whether both mechanisms operate. The purpose of the present communication is to discuss the result of a series of recent experiments which at least in part resolve this uncertainty.

\section{Meiotic inductor substance (MIS).}

It is well known that ovaries removed from early embryos cannot be maintained in organ culfure : the germ cells fail to enter meiosis and subsequently degenerate (mouse : Wolff, 1952 ; hamster : Challoner, 1975 ; sheep : Mauleon, 1973). By contrast, meiosis can proceed normally in vitro if the ovaries are recovered after a critical stage of gonadal development (Martinovitch, 1938 ; Borghese and Venini, 1956 ; Baker and Neal, 1973 ; Challoner, 1975). These results clearly indicate that a specific substance has to be produced for a short period of time (less than $24 \mathrm{~h}$ in the

(1) Address for all correspondence : Wai-sum O, Harvard Medical School, Laboratory of Human Reproduction and Reproductive Biology, 45 Shattuck Street, Boston, Mass. 02115, U. S. A. 
mouse) to permit the onset of meiosis, but provide no information as to origin of the inductor substance.

Byskov (1974) transplanted fetal ovaries into nude mice and showed that meiosis in female germ cells was only « triggered » in an ovary if the rete ovarii was present in the transplant : in the absence of the rete, meiosis failed to occur. Studies of the histology of cat, mink and ferret ovaries (Byskov, 1975) showed that there is cellular contact between rete and germinal cells in the medullary region of the ovary, where meiosis is first observed, and that the further proliferation of the rete could account for the subsequent induction of meiosis in peripheral germ cells. The actual meiotic inductor substance has not been identified but may be related to the PAS-positive granules found in the cells of the rete (Byskov, 1975). Recent studies employing organ culture of ovaries with and without the rete ovarii and/or mesonephros (which almost certainly have a common origin) have confirmed the vital role of MIS (O and Baker, 1976 ; Rivelis ef al., 1976).

The failure of male germ cells in a testis to enter meiosis during fetal life could be due to their early envelopment within seminiferous tubules preventing the ingress of MIS. Alternatively, as Burgoyne (1977) has suggested, the Y-chromosome may play a role in "switching-off» the early action of the rete and/or MIS. It has now been repeatedly shown, however, that the rete ovarii can induce meiosis in testicular germ cells. When fetal testes and ovaries (with rete) are cocultured on opposite sides of a Millipore filter of suitable pore size, germ cells in both the ovary and testis enter meiosis, suggesting the presence of a diffusible factor (mouse : Byskov and Saxen, 1976 ; hamster : 0, 1977). It is interesting to note that disorganization of the seminiferous tubules, resulting in extra-tubular germ cells, is always observed in testes in which germ cells have entered meiosis (0 and Baker, 1976), but it remains unknown whether such a disorganisation is a primary or secondary effect of MIS.

These experiments show that both male and female germ cells can enter meiosis during fetal life and that a diffusible factor probably emanating from the reteovarii (which is derived from the mesonephros) is the inductor substance. More definitive evidence derives from studies of chimaeric mice, made by aggregating 8-cell cleavage stage embryos, or injecting $X X$ (or $X Y$ ) cells into the blastocoel of $X Y$ (or $X X$ ) blastocysts (both of which are considered below as « natural » chimaeras), and by making "artificial gonads » by aggregating $X X$ germ cells with $X Y$ somatic cells (and vice versa).

\section{Natural $X X / X Y$ chimaeric mice.}

When two 8-cell cleavage stage embryos are fused together, at large proportion of these $X X \leftrightarrow X Y$ chimaeras develop as males and only a small proportion develop as females (see Ford and also Burgoyne, 1978 ; also McLaren, 1976). The question remains as to whether the genotype of the somatic cells can influence the fate of the germ cells.

Studies of $X X \leftrightarrow X Y$ fetal mouse chimaeras have shown that the gonads are normally testes and a proportion of the germ cells enter meiosis between Days $14 \frac{1}{2}$ and $18 \frac{1}{2}$ post conception (Mystokowska and Tarkowski, 1968 ; Kofman-Alfaro and 
Chandley, 1970). The characteristic « late-labelling » pattern of the $Y$ chromosome with tritiated thymidine was not observed in the cells which entered meiosis and thus it was concluded that only the $X X$ cells were involved. The meiotic germ cells (seemingly $X X)$ seemed to be unable to survive in the testicular environment such thatlater in development, only $X Y$ cells should be encountered.

There is no evidence available as to whether the somatic cells surrounding the germ cells affect their differentiation and thus whether it is the $X X$ somatic cells which induce meiosis in $X X$ germ cells. The limitation of the mouse chimaera as a model of gonadal differentiation is that "patch size " for each cell type cannot be determined.

Steinberger and Steinberger (1966) and Yamada ef al. (1973) have developed techniques permitting the separation of germinal and somatic cells from gonads. By reaggregating germ cells of one sex with somatic cells of the opposite sex, an "artificial » chimaeric gonad can be made and cultured, thereby making it possible to study the fate of germ cells in a genetically « inappropriate » somatic environment.

\section{« Artificial » Chimaeric gonads.}

Hamster gonads, recovered on Day 12 post conception, can readily be sexed by exmining liver cells for the presence of a sex chromatin body. Gonads of the same sex are then pooled together (ca 25-30 gonads per group) and their somatic and germinal cells separated using $0.25 \mathrm{p}$. 100 trypsin in phosphate-buffered saline (with added DNA-ase) at $32{ }^{\circ} \mathrm{C}$ for $20 \mathrm{~min}$. After washing the cells to remove the trypsin, they

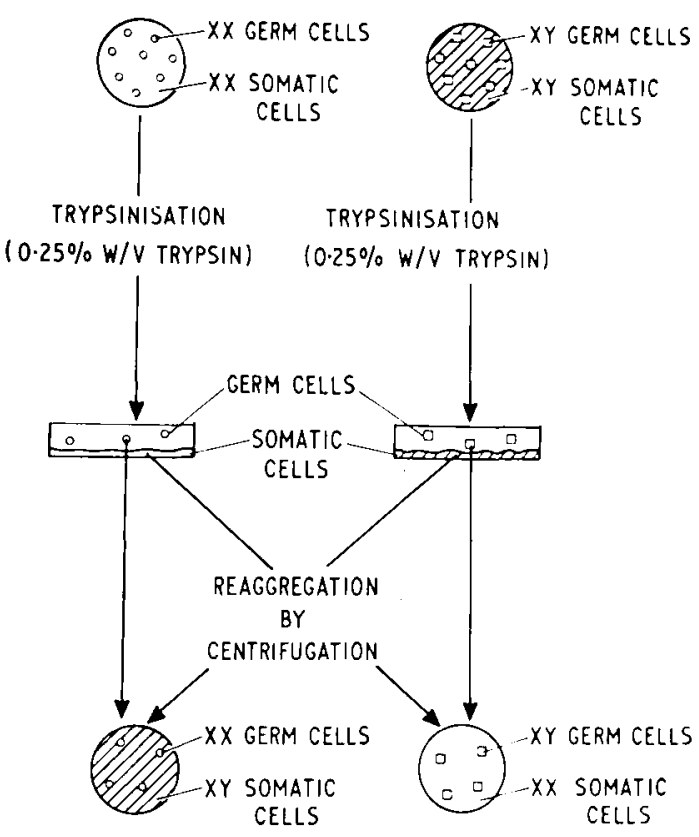

FIG. 1. - Diagram to show the stages in the preparation of the "arlificial " chimaeric gonad. Circles represent female germ cells while squares represent male germ cells. 
were cultured overnight in Eagle's minimal essential medium (with Earle's salts and Hepes buffer and 20 p. 100 new-born calf serum). In this way the somatic cells became attached to the plastic Petri dish while the germ cells remained free-floating in the medium (see fig. 1). Germ cells were harvested by centrifugation of the supernatant medium, after which the somatic cells were recovered by mild trypsinization of the Petri dishes.

Once the cell separations had been checked for viability and purity (lack of germ cells in the somatic cell preparation and vice versa) and a pellet was made by centrifuging the cells at $900 \mathrm{rpm}$ for $15 \mathrm{~min}$. The pellet was transferred to an agar block (previously equilibrated with culture medium) and cultured for 3 to 8 days using the methods of Baker and Neal (1973). At the end of the period of culture the " artificial 》 chimaeric gonads (still attached to their agar blocks) were processed for histology and slides stained with haematoxylin and eosin were examined to assess the stage of gonadal/germ cell differentiation.

TABLE 1

Fate on germ cells in « artificial » chimaeric gonads

\begin{tabular}{|c|c|c|c|c|}
\hline & \multicolumn{2}{|c|}{ Controls } & \multicolumn{2}{|c|}{ Chimaeras } \\
\hline & $X \times G / X \times S$ & $X Y G / X Y S$ & $X X G / X Y S$ & $X Y G / X X S$ \\
\hline $\begin{array}{l}\text { Age (days p. c.) } \ldots \ldots \ldots \ldots \\
\text { No. cultures } \ldots \ldots \ldots \ldots \\
\text { Germ cell survival } \ldots \ldots \ldots \\
\text { Meiosis induced } \ldots \ldots \ldots \ldots\end{array}$ & $\begin{array}{r}12 \\
5 \\
+ \\
+ \\
-\end{array}$ & $\begin{array}{r}12 \\
5 \\
+ \\
-\end{array}$ & $\begin{array}{r}12 \\
5 \\
- \\
-\end{array}$ & $\begin{array}{r}12 \\
5 \\
t- \\
t-\end{array}$ \\
\hline
\end{tabular}

$\underline{G}=$ germ cell genotype $; \underline{S}=$ somatic cell genotype.

In these experiments, the controls were aggregated cells of the same genotypes prepared and cultured under identical conditions. The development of these controls was similar to that of organ cultured intact gonads. Female germ cells entered meiosis while their (female) somatic cells remained fairly disorganised, while male germ cells did not enter meiosis and their male somatic cells reorganised into tubules around them (Plate la and $b$ ).

\section{PLATE I}

la. $-X X$ somatic/XX germinal gonad cultured for 6 days. Most germ cells $(G)$ entered meiosis while some become atretic (arrowed) $(\times 210)$.

Ib. $-X Y$ somatic/ $X Y$ germinal gonad cultured for 6 days. The germ cells $(G)$ regrouped together $(X 500)$.

Ic. $-X X$ somatic/ $X Y$ germinal gonad after 8 day in culture. The nuclei of the $X Y$ germ cells became grainy in appearance. A germ cell $(M)$ in meiosis is shown ( $\times 210)$.

Id. $-X Y$ somatic/XX germinal gonad culfured for 6 days. No germ cell survived $(\times 210)$. 
By contrast, the developement of the $X X / X Y$ artificial gonad was quite different to that of the controls and organ cultured whole gonads, $X X$ somatic cells remained dispersed around $X Y$ germ cells : seminiferous tubules did not form and after 6-8 days in culture the male germ cells became " grainy 》 in appearance and some of them entered meiosis (Plate $I c$ ). In contrast, $X X$ somatic cells did not survive when surrounded by $X Y$ somatic cells and the latter did not form seminiferous tubules (Plate Id).

The failure of $X X$ germ cells to survive in the $X Y$ environment is in keeping with results from other studies. A similar situation occurs in sex-reversed mice, $X X$ male goats and pigs, and in freemartin gonads ( 0 and Short, 1977). Similarly, in $X X \leftrightarrow X Y$ chimaeric mice progeny testing has revealed that only the $X Y$ germ cells survive (McLaren, 1976).

The fate of $X Y$ germ cells in an ovary is more difficult to determine. The results described in the present study clearly show that male germ cells can enter meiosis but provide no evidence as to their eventual fate. However, Evans et al. (1977) have recently found an $X Y$ oocyte in a rare case of a female $X X \leftrightarrow X Y$ chimaera, indicating that $X Y$ oocytes can at least occasionally survive to sexual maturity.

$27^{\mathrm{e}}$ Congrès international des Sciences physiologiques, Symposium « Germ and somatic cell interaction 》 Paris, 21-23 juillet 1977.

Acknowledgments. - The expenses incurred in this study were provided by the Medical Research Council, and from grants to T. G. Baker by the Population Council and the Ford Foundation. The authors are grateful to Professor R. V. Short for his comments on the manuscript.

Résumé. L'influence des cellules somatiques affectant la différenciation et le dévelopipement des cellules germinales durant la différenciation de la gonade est discutée. Nous avons confirmé que sous l'influence du rete ovarii les cellules germinales mâles aussi bien que les cellules germinales femelles peuvent entrer en méiose. Les relations entre cellules germinales et cellules somatiques ont également été étudiées dans des gonades chimères artificielles dans lesquelles les cellules germinales ef les cellules somatiques sont de sexes opposés. Il apparaît que les cellules germinales $X Y$ peuvent survivre parmi des cellules somatiques $X X$ et entrent en méiose précocement, tandis que les cellules germinales $X X$ ne peuvent survivre parmi des cellules somatiques $X Y$.

\section{References}

BAKER T. G., NEAL P., 1973. Initiation and control of meiosis and follicular growth in ovaries of the mouse. Ann. Biol. anim. Biochim. Biophys., 13, 137-144.

BAKER T.G., O.W.S., 1976. Development of the ovary and oogenesis, 3-36. In MacNAUGHTON M. C., GOVAN A. D. T., Clinics in Obstetrics and Gynaecology, Vol. 3, Saunders Co. Ltd, London.

BORGHESE E., VENINI M. A., 1956. Culture in vitro de gonadi embrionali di Mus musculis. Symp. Genet., 5, 69-83.

BURGOYNE P. S., 1977. The genetics of sex in development. In HAMILTON D. W., NAFTOLIN F., SHANE J. M., The essentials of reproductive biology : Bosis for clinical practice. MIT Press, Boston (in press). 
BURGOYNE P. S., 1978. The role of the sex chromosomes in mammalian germ cell differentiation. Ann. Biol. onim. Bioch. Biophys., 18, 317-325.

BYSKOV A. G., 1974. Does the rete ovarii act as a trigger for the onset of meiosis ? Nature, Lond. 252, 396-7.

BYSKOV A. G., 1975. The role of the rete ovarii in meiosis and follicle formation in different mammalian species. J. Reprod. Ferf., 45, 201-209.

BYSKOV A. G., SAXEN L., 1976. Induction of meiosis in fetal mouse testis in vitro. Develop. Biol., 52, 193-200.

CHALLONER S., 1975. Studies of oogenesis and follicular development in the golden hamster. 2. Initiation and control of meiosis in vitro. J. Anat., 119, 149-156.

EVANS E. P., FORD C. E., LYON M. F., 1977. Direct evidence of the capacity of the germ XY cell in the mouse to become an oocyte. Nature, Lond., 267, 430-431.

KOFMAN-ALFARO S., CHANDLEY A., 1970. Meiosis in the male mouse : an autoradiographic investigation. Chromosoma, 31, 404-420.

MARTINOVITCH P. N., 1938. Development in vitro of the mammalian gonad. Ovary and oogenesis. Proc. roy. Soc., 235, 232-249.

MAULEON P., 1973. Modification expérimentale de l'apparition et de l'évolution de la prophase méiotique dans l'ovaire d'embryon de brebis. Ann. Biol. anim. Bioch. Biophys., 13, no hors série, 89-102.

MCLAREN A., 1976. Mammolian chimaeras. Cambridge Univ. Press, Cambridge.

MYSTOKOWSKA E. T., TARKOWSKI A. K., 1968. Observations in CBA-P/CBA-T6T6 mouse chimaeras. J. Embryol. exp. Morphol., 20, 33-52.

O W. S., 1977. Gonadal sex determination and differentiation in rats and hamsters. Ph. D. Thesis, Edinburgh Univ.

O W. S., BAKER T. G., 1976. Initiation and control of meiosis in hamster gonads in vitro. J. Reprod. Fert. 48, 399-401.

OW. S., SHORT R. V., 1977. Sex determination and differentiation in mammalian germ cells, 1-12, In BLANDAU R. J., BERGSMA D., Morphogenesis and malformation of the genital system. Alan. R. Liss Inc., Nat. Found.

RIVELIS C., PREPIN J., VIGIER B., JOST A., 1976. Prophase méiotique dans les cellules germinales de l'ébauche ovarienne de rat cultivée in vitro en milieu anhormonal. C. R. Acod. Sci., Paris, Sér. D., 282, 1429-1432.

STEINBERGER A., STEINBERGER E., 1966. In vitro culture of rat testicular cells. Exp. Cell Res., 44, 443-452.

WOLFF E., 1952. Sur la differentiation sexuelle des gonades de souris explantee in vitro. C. $R$ Acad. Sci., Paris, 234, 1712-1714.

YAMADA M., YASUE S., MATSUMOTO K., 1973. Formation of $C_{21}$-17-hydroxysteroids and $C_{19}$-steroid from $3 \beta$-hydroxy-preg-5-en-20-one and progesterone in vitro by germ cells from immature rat testis. Endocrinology, 93, 81-89.

ZUCKERMAN S., BAKER T. G., 1977. The development of the ovary and the process of oogenesis, 42-68. In ZUCKERMAN S., WEIR B. J., The ovary, Vol. 1, 2nd ed., Acad. Press, New York. 